\title{
Safety, efficacy and outcomes of the new Greenlight XPS 180W laser system compared to the GreenLight HPS 120W system for the treatment of benign prostatic hyperplasia in a prospective nonrandomized single-centre study
}

\author{
Alper Eken, MD, FEBU; ${ }^{*}$ Bulent Soyupak, MD; ${ }^{\dagger}$ Meltem Acil, MD; ${ }^{\ddagger}$ Taner Arpaci, MD; ${ }^{*}$ Tugana Akbas, MD*
}

*Acibadem University Vocational School of Health Services, Department of Urology, Adana, Turkey; ${ }^{\dagger}$ Acibadem Adana Hospital Department of Urology, Adana, Turkey; ${ }^{\S}$ Acibadem University Department of Anesthesiology and Reanimation, Adana, Turkey; ${ }^{*}$ Acibadem University Vocational School of Health Services, Department of Radiology, Adana, Turkey

Cite as: Can Urol Assoc J 2015;9(1-2):e56-60. http://dx.doi.org/10.5489/cuai.2263 Published online February 9, 2015.

\section{Abstract}

Introduction: We compare and evaluate the safety, efficacy, and short-term outcomes of the new GreenLight XPS 180W (GL-XPS) laser system with the former generation GreenLight HPS 120W (GL-HPS) system for the treatment of benign prostatic hyperplasia $(\mathrm{BPH})$ in a prospective nonrandomized single-centre study.

Methods: From May 2012 to June 2013, 161 consecutive patients with lower urinary tract symptoms secondary to $\mathrm{BPH}$ were included: 88 patients were treated with the GL-HPS system and 73 were treated with the GL-XPS system. The perioperative variables International Prostate Symptom Score (IPSS), quality of life (QOL), and maximum flow rate (Qmax) were recorded at baseline, at one month and 6 months. Serum prostate-specific antigen (PSA) was assessed at baseline.

Results: The mean age was 70.2 years in the GL-HPS group and 68.6 years in the GL-XPS group. Prostate volumes were $62.3 \mathrm{~mL}$ and $61.3 \mathrm{~mL}$, respectively. Both groups showed significant postoperative improvement in the IPSS, QOL, Qmax variables compared to baseline levels. There were no significant differences in improvement in IPSS and QOL between groups. However, both operating and catheterization times were shorter in patients in the GL-XPS group. The overall postoperative complication rate was similar in both groups.

Conclusion: Both GreenLight systems provide safe, effective tissue vaporization with significant clinical relief of BPH obstruction. The GL-XPS system appears more favourable with regard to reduced operating and hospitalization time, suggesting more cost-effective and efficient tissue removal.

\section{Introduction}

Benign prostatic hypertrophy, otherwise known as "benign prostatic hyperplasia (BPH)," is a general problem that causes bladder outlet obstruction (BOO) among aging males. ${ }^{1,2}$ Transurethral resection of the prostate (TURP) and open prostatectomy are usually considered gold standard treatment options in these patients. ${ }^{3-5}$ The remarkable risk of mortality and morbidity of both procedures, especially TURP syndrome and bleeding, has prompted the search for minimally invasive laser-based techniques. ${ }^{6}$ Photoselective vaporization of the prostate (PVP) is widely used and has been extensively studied with different systems, such as the 80W KTP laser, the GreenLight HPS $120 \mathrm{~W}$ (GL-HPS) system (American Medical Systems, Minnetonka, MN), and most recently the GreenLight XPS 180W (GL-XPS) system. PVP has been highlighted for use in patients taking oral anticoagulant medications. ${ }^{7}$ The mechanism of PVP lies in its selective absorption of oxyhemoglobin in the prostate, allowing photovaporization of prostate tissue, thereby reducing intra-operative bleeding.

Although PVP is considered a safe and cost-effective technique for removing an enlarged prostate, systems with different power densities show significantly varied results. The GL-HPS system is accompanied by significant fibre design changes (i.e., a change to MoXy fibre) and a 50\% increase in beam area compared to its predecessor, the GL-PV 80. The GL-XPS system results in significantly superior tissue ablation compared to the GL-PV $80 .^{8}$ Moreover, it is challenging to operate on prostates with large volumes with the GL-HPS or with the GL-PV 80. Because of the issues with earlier generation PVP lasers, the GL-XPS system has been the most widely recommended. However, due to its novelty, only a few human studies have investigated its efficacy, preoperative complication rates and other side effects. Bachmann and colleagues ${ }^{9}$ evaluated early safety and efficacy in 201 procedures performed worldwide and determined that the GL-XPS system is safe and effective for treating lower urinary tract symptoms (LUTS) linked with BPH. Although their findings showed a reduction in operation time and no complica- 
tions, the authors were cautious about whether the system produced short-term outcomes similar to those of previous systems. Ben-Zvi and colleagues ${ }^{10}$ also found that both the GL-XPS system and its predecessor are safe and effective, and further found that the GL-XPS system was favourable regarding PSA reduction, reduced fibre use, and operation time. Hueber and colleagues ${ }^{11}$ also concluded that the new GL-XPS system exhibits significant advantages in all surgical parameters.

Only a limited number of human studies have been conducted to assess the clinical response and operation outcomes of the GL-XPS compared to those of the GL-HPS. We compare the efficacy and safety of the new GL-XPS laser system to that of the former generation GL-HPS system.

\section{Methods}

\section{Study population}

Institutional Ethical Board approval was obtained prior to data collection. Of the 161 patients who were diagnosed with LUTS secondary to BPH, 73 were treated using the GL-XPS system and 88 were treated using the GL-HPS system. A single surgeon performed all procedures, and patients were treated from May 2012 to June 2013. All data were collected and recorded prospectively. All patients were treated with the intent of conducting the surgery on the same day unless complications arose. No residents participated in the study.

Surgery indications were chosen based on criteria set by the American Urological Association ${ }^{6}$ and the European Association of Urology. ${ }^{12}$ We tallied patient baseline parameters and operation outcomes (Table 1). We included patients on anticoagulant medication and those who were catheterized before surgery or had a history of urinary retention. Patients on anticoagulant medication were suspended from using aspirin 7 days before surgery and allowed to proceed 7 days after the surgery. Warfarin use was also suspended for about 5 days and then started again to normalize the international normalized ratio (INR), which was considered normal at $<1.3$. Surgery was also allowed for patients with values near normal (range: 1.3-1.4).

We excluded patients with known neurologic disorders, urogenital trauma, bladder neck stricture, evidence of active urinary tract infection, spinal cord injury, prostatic malignancy, bladder tumours, neurogenic bladder, urethral stricture, or earlier prostatic surgery. This was done because postoperative complications could have been confused with pre-existing bladder dysfunction or voiding problems in these patients.

Surgical procedures were performed in accordance with descriptions given by International GreenLight users group
(IGLU modular technique). ${ }^{13}$ All procedures were done under spinal anesthesia with sedation. A combination of MoXy fibre with the GL-XPS was used throughout the whole procedure, and pure vaporization was used. Room temperature saline was used as irrigant in a $22 \mathrm{~F}$ Laser cystoscope and the largest power setting was $180 \mathrm{~W}$, adjustable in 10-W steps.

\section{Assessment}

Both standard parameters associated with transurethral prostate surgery and surgery-associated symptoms and complications were prospectively documented. Assessments were made preoperatively and at 1 month and 6 months after the operation. At the preoperative assessment, patients were evaluated for prostate volume $(\mathrm{mL})$, quality of life score (QoL), International Prostate Symptom Score (IPSS), and maximum urinary flow rate $(\mathrm{Qmax}, \mathrm{mL} / \mathrm{s})$. The preoperative evaluations also included physical examination, complete medical history, serum prostate-specific antigen (PSA, ng/ $\mathrm{mL}$ ), electrolytes, urine and blood sample analysis, and renal function markers. If a patient had an abnormal digital rectal examination or elevated serum PSA, a transrectal ultrasound (TRUS)-guided biopsy was performed to rule out prostate cancer. The operation parameters recorded were lasing time, energy usage $(\mathrm{kJ})$, and operating time. Clinical outcomes were determined postoperatively and changes from preoperative values were measured at 1 month and 6 months.

\section{Statistical analysis}

Statistical tests were performed using the SPSS Statistics v.19.0 software package (IBM Corp.). For numerical data, independent sample t-tests were performed; for comparisons of before and and after surgery, the paired-sample t-test was performed. For categorical data, the Chi-square test was used. In two-sided tests, $p<0.05$ was considered statistically significant. Statistical results were presented as mean \pm standard deviation (SD) along or as a percentage of total patients. To evaluate predictive factors related to surgery-related complications or symptoms, logistic regression was used. Odds ratios (OR) with 95\% confidence intervals $(95 \% \mathrm{Cls})$ were calculated and reported.

\section{Results}

A cohort of 161 male patients was used (Table 1). The mean patient age was 70 . About $30 \%$ of patients had been sent to our clinic with their Foley catheter, which caused the high post-void residual (PVR) urine volume. Before surgery, 52 patients were using anticoagulants (Table 2).

In total, 88 patients underwent laser PVP therapy using the GL-HPS system, and 73 patients were treated using the 
Eken et al.

\begin{tabular}{|c|c|c|c|}
\hline \multirow[t]{2}{*}{ Parameters } & $\begin{array}{l}\text { HPS } 120 \text { Watt } \\
(n=88)\end{array}$ & $\begin{array}{l}\text { XPS } 180 \text { Watt } \\
(n=73)\end{array}$ & \multirow[t]{2}{*}{$p$ value } \\
\hline & Mean (min-max) & Mean (min-max) & \\
\hline \multicolumn{4}{|l|}{ Baseline } \\
\hline Age & $70.20(50-83)$ & $68.66(49-86)$ & 0.182 \\
\hline PSA & $2.93(0.5-10.2)$ & $2.79(0.4-15.1)$ & 0.679 \\
\hline Prostate volume & $62.32(28-128)$ & $61.30(27-142)$ & 0.786 \\
\hline PVR (mL) & $320(35-740)$ & $305(30-700)$ & 0.720 \\
\hline $\begin{array}{l}\text { Operating time } \\
\text { (minute) }\end{array}$ & $58.67(28-98)$ & $46.89(25-95)$ & $<0.05$ \\
\hline Lasing time & $32.63(13-53)$ & $29.71(12-66)$ & 0.076 \\
\hline $\begin{array}{l}\text { Applied energy } \\
\text { (Joule) }\end{array}$ & $228.34(58-445)$ & $248.42(89-568)$ & 0.167 \\
\hline $\begin{array}{l}\text { Catherization time } \\
\text { (hour) }\end{array}$ & $23.23(14-72)$ & $17.63(6-69)$ & $<0.05$ \\
\hline IPSS preoperative & $24.83(16-32)$ & $23.73(15-33)$ & 0.109 \\
\hline $\begin{array}{l}\text { QoL score } \\
\text { preoperative }\end{array}$ & $4.55(3-6)$ & $4.58(3-6)$ & 0.815 \\
\hline $\begin{array}{l}\text { Average flow } \\
\text { preoperative }\end{array}$ & $4.03(2-6)$ & $4.22(3-6)$ & 0.137 \\
\hline Qmax preoperative & $7.24(4.8-11.4)$ & $7.38(5.3-12.4)$ & 0.515 \\
\hline \multicolumn{4}{|l|}{ Follow-up (6 months) } \\
\hline IPSS postoperative & $8.97(2-21)$ & $8.27(2-24)$ & 0.189 \\
\hline PVR (mL) & $35(0-95)$ & $40(0-100)$ & 0.325 \\
\hline $\begin{array}{l}\text { QoL score } \\
\text { postoperative }\end{array}$ & $1.35(0-4)$ & $1.22(0-4)$ & 0.355 \\
\hline $\begin{array}{l}\text { Average flow } \\
\text { postoperative }\end{array}$ & $7.85(4.3-11.3)$ & $8.34(5.4-12.4)$ & $<0.05$ \\
\hline $\begin{array}{l}\text { Qmax } \\
\text { postoperative }\end{array}$ & $17.82(7.6-26.2)$ & $18.83(10.0-27.2)$ & $<0.05$ \\
\hline
\end{tabular}

GL-XPS system. There were no statistically significant differences in the baseline values of mean age, PSA, prostate volume, PVR, lasing time, applied energy, IPSS, QOL score, and Qmax between groups. However, both the mean operation time and mean catheterization time were higher in the GL-HPS group; these differences were statistically significant. The surgeon decided when to remove the catheter based on the urine colour (Table 1$)$. Substantially higher mean values of average flow $(p=0.02)$ and $Q \max (p=0.01)$ were observed in the GL-HPS group at follow-up (Table 1).

Table 3 illustrates the relationship between complications and which system was used. No significant differences $(p>0.05)$ in any of basic parameters were observed either at baseline or at any of the follow-up time points between groups (Table 4.) The mean change in IPSS from baseline was 15.86 and 15.45 in the GL-HPS and GL-XPS groups, respectively. Mean improvements in average flow were $3.8 \mathrm{~mL} / \mathrm{s}$ and $4.1 \mathrm{~mL} / \mathrm{s}$ in the GL-HPS and GL-XPS groups, respectively. Qmax improvement was also greater in the GL-XPS group.

\begin{tabular}{|c|c|c|c|c|c|}
\hline \multirow{3}{*}{ Anticoagulant } & \multicolumn{4}{|c|}{ Watt type } & \multirow{3}{*}{$p$ value } \\
\hline & \multicolumn{2}{|c|}{ HPS 120 Watt } & \multicolumn{2}{|c|}{ XPS 180 Watt } & \\
\hline & $\mathbf{N}$ & $\%$ & $\mathbf{N}$ & $\%$ & \\
\hline Aspirin & 16 & 18.2 & 14 & 19.2 & \\
\hline Clexane & 4 & 4.5 & 4 & 5.5 & \\
\hline Clopidogrel & 8 & 9.1 & 3 & 4.1 & 0.896 \\
\hline Coumadin & 1 & 1.1 & 2 & 2.7 & \\
\hline Total & 29 & 32.9 & 23 & 31.5 & \\
\hline
\end{tabular}

Twenty-nine patients (32.9\%) experienced at least 1 adverse event in the GL-HPS group, while 21 (28.7\%) did in the GL-XPS group. Overall, 50 adverse events were reported (Table 4). There was no significant relationship between complication and the type of system $(p=0.230)$.

\section{Discussion}

The most common urological disorder in men is $\mathrm{BPH}$. In the present study, we highlighted the efficacy, safety, and outcomes of the GL-HPS laser system compared to the newer GL-XPS laser system. Some standard parameters were improved in the GL-XPS laser system, namely higher energy, reduced operation time, faster speed of lasing, and more efficient tissue removal.

The GL-XPS system is safe and effective to treat LUTS secondary to $\mathrm{BPH} .{ }^{9}$ The present comparative study was conducted between the earlier reported studies on the GL-HPS system and on the GL-XPS system. The GL-XPS provides equivalently limited outcomes with reduced operating time and few complications. A safety study with the GL-XPS laser showed no serious interoperative complications, such as transfusion, TURP syndrome, and bleeding. ${ }^{9-11}$ Woo and colleagues ${ }^{14}$ and Ruszat and colleagues ${ }^{15}$ recently reported no

\begin{tabular}{|c|c|c|c|c|c|}
\hline & \multirow[t]{3}{*}{ Complication } & \multicolumn{4}{|c|}{ Watt type } \\
\hline & & \multicolumn{2}{|c|}{$\begin{array}{l}\text { HPS } 120 \\
\text { Watt }\end{array}$} & \multicolumn{2}{|c|}{$\begin{array}{l}\text { XPS } 180 \\
\text { Watt }\end{array}$} \\
\hline & & $\mathbf{N}$ & $\%$ & $\mathbf{N}$ & $\%$ \\
\hline \multirow{3}{*}{ Postoperative } & Transient hematuria & 4 & 4.5 & 4 & 5.5 \\
\hline & Temporary retention & 5 & 5.7 & 3 & 4.1 \\
\hline & Urinary retention & 3 & 3.4 & 3 & 4.1 \\
\hline \multirow{3}{*}{1 month } & $\begin{array}{l}\text { Re-intervention } \\
\text { (TURP) }\end{array}$ & 2 & 2.3 & 1 & 1.4 \\
\hline & Urge incontinence & 4 & 4.5 & 3 & 4.1 \\
\hline & Dysuria & 7 & 7.9 & 5 & 6.8 \\
\hline \multirow{3}{*}{6 months } & Urge incontinence & 1 & 1.1 & 1 & 1.4 \\
\hline & $\begin{array}{l}\text { Bladder neck } \\
\text { contracture }\end{array}$ & 2 & 2.3 & 1 & 1.4 \\
\hline & Urethral stricture & 1 & 1.1 & - & - \\
\hline
\end{tabular}

TURP: transurethral resection of the prostate. 


\begin{tabular}{|c|c|c|c|c|c|c|c|c|c|c|c|c|}
\hline \multirow{4}{*}{ Parameter } & \multicolumn{12}{|c|}{ Watt type } \\
\hline & \multicolumn{6}{|c|}{ HPS 120 watt ( $n=88$ ) } & \multicolumn{6}{|c|}{ XPS 180 Watt $(n=73)$} \\
\hline & \multicolumn{2}{|c|}{ Baseline } & \multicolumn{2}{|c|}{1 month } & \multicolumn{2}{|c|}{6 months } & \multicolumn{2}{|c|}{ Baseline } & \multicolumn{2}{|c|}{1 month } & \multicolumn{2}{|c|}{6 months } \\
\hline & $\begin{array}{c}\text { Mean } \pm \\
\text { SD }\end{array}$ & Median & $\begin{array}{c}\text { Mean } \pm \\
\text { SD }\end{array}$ & Median & $\begin{array}{c}\text { Mean } \pm \\
\text { SD }\end{array}$ & Median & $\begin{array}{c}\text { Mean } \pm \\
\text { SD }\end{array}$ & Median & $\begin{array}{c}\text { Mean } \pm \\
\text { SD }\end{array}$ & Median & $\begin{array}{c}\text { Mean } \pm \\
\text { SD }\end{array}$ & Median \\
\hline IPSS & $25 \pm 4$ & 25 & $11 \pm 4$ & 11 & $9 \pm 4$ & 9 & $24 \pm 5$ & 24 & $10 \pm 3$ & 10 & $8 \pm 3$ & 8 \\
\hline PVR & $320 \pm 285$ & 295 & $70 \pm 50$ & 80 & $35 \pm 60$ & 40 & $305 \pm 300$ & 290 & $60 \pm 45$ & 80 & $40 \pm 60$ & 45 \\
\hline QoL score & $5 \pm 1$ & 5 & $2 \pm 2$ & 2 & $1 \pm 1$ & 1 & $5 \pm 1$ & 5 & $2 \pm 2$ & 2 & $1 \pm 1$ & 1 \\
\hline Average flow & $4 \pm 1$ & 4 & $7.4 \pm 1.4$ & 7.2 & $7.9 \pm 1.2$ & 7.6 & $4 \pm 1$ & 4 & $7.7 \pm 1.8$ & 7.4 & $8.3 \pm 1.4$ & 8.0 \\
\hline Qmax & $7.2 \pm 1.3$ & 7.1 & $6.3 \pm 3.0$ & 15.2 & $17.8 \pm 2.6$ & 17.6 & $7.4 \pm 1.3$ & 7.2 & $17.2 \pm 2.8$ & 17.5 & $18.8 \pm 2.3$ & 18.6 \\
\hline
\end{tabular}

PSA: prostate-specific antigen; IPSS: International Prostate Symptom Score; Qmax: maximum flow rate; QOL: quality of life; PVR: post-void residual; SD: standard deviation.

significant differences in adverse effects between the two systems and concluded that the GL-XPS system is an effective treatment option.

Ben-Zvi and colleagues ${ }^{10}$ concluded that both these systems provide safe and effective tissue vaporization and significant clinical relief for BPH; the GL-XPS system was more efficient at tissue removal and more cost-effective because of its decreased fibre use and decreased associated operation time. In the present study, the GL-XPS system was associated with a reduced operation time, while the lasing time was similar. Hence, the total operating time is less with the GL-XPS system.

The IPSS at baseline and at follow-up was not significantly different between treatment groups in the present study, whereas in previous studies, the IPSS was significantly different in inter groups of GL-HPS. ${ }^{16}$ The change in Qmax and IPSS observed in the current study were comparable to those found in earlier reports, ${ }^{17-22}$ that is, reduced from baseline values in both groups. The maximum flow rate was increased in both groups at the 6-month follow-up. Other parameters at baseline and at the 6-month follow-up were not significantly different between groups. Malek and colleagues, ${ }^{23}$ in their comparative study of GL-XPS and GL-HPS in canine prostate, found the GL-HPS laser slower in tissue removal compared with the GL-XPS laser, although the ex vivo observations are yet to be confirmed in human clinical trials. In addition, Hueber and colleagues, ${ }^{11}$ studied 1809 patients who underwent laser PVP; they also concluded that the new GL-XPS system exhibited significant advantages in all surgical parameters compared with the former GL-HPS system.

In our study, rates of urinary infection and postoperative urinary retention were low in both groups, consistent with previous findings on GL-HPS in laser prostatectomy. ${ }^{22}$ The major complications that were reported in both groups were dysuria ${ }^{16,19}$ and hematuria. ${ }^{18-22}$ In other studies, complications from treatment with the GL-HPS system included capsule perforation, bleeding and conversion to TURP..$^{16-20}$
The GL system is thought to be very effective and safe for aspirin consumers. In the current study, more patients in both groups used aspirin than used other anticoagulants. Shon and colleagues ${ }^{24}$ studied patients who were taking anticoagulant medication for cardiac or cerebral diseases and found both laser systems to be effective.

The limitations of our present study include the short-term follow-up, the limited number of patients, and performance of all treatments by a single surgeon.

\section{Conclusion}

Both the GL-XPS and the GL-HPS systems provide safe, effective tissue vaporization of an enlarged prostate gland, as determined by PVP treatment outcomes. The GL-XPS system is associated with decreased operation time, suggesting more efficient tissue removal and cost-effectiveness. Future clinical trials are needed to estimate the true efficacy and success of the GL-XPS system.

Competing interests: Authors declare no competing financial or personal interests.

This paper has been peer-reviewed.

\section{References}

1. Chapple CR, Roehrborn CG. A shifted paradigm for the further understanding, evaluation, and treatment of lower urinary tract symptoms in men: Focus on the bladder. Eur Urol 2006;49:651-8. http://dx.doi. org/10.1016/j.eururo.2006.02.018

2. Berry SJ, Coffey DS, Walsh PC, et al. The development of human benign prostatic hyperplasia with age. J Urol 1984;132:474-9.

3. Rassweiler J, Teber D, Kuntz R, et al. Complications of transurethral resection of the prostate (TURP) - incidence, management, and prevention. Eur Urol 2006;50:969-79. http://dx.doi.org/10.1016/i. eururo.2005.12.042

4. YU X, Elliott SP, Wilt TJ, et al. Practice patterns in benign prostatic hyperplasia surgical therapy: The dramatic increase in minimally invasive technologies. J Urol 2008;180:241-5. http://dx.doi.org/10.1016/i. juro.2008.03.039

5. Miano R, De Nunzio C, Asimakopoulos AD, et al. Treatment options for benign prostatic hyperplasia in older men. Med Sci Monit 2008;14:RA94-102. 
Eken et al.

6. American Urological Association Education and Research Inc. American Urological Association Guideline: Management of benign prostatic hyperplasia (BPH); 2010. https://www.auanet.org/common/pdf/ education/clinical-guidance/Benign-Prostatic-Hyperplasia.pdf. Accessed February 2, 2015.

7. Ruszat $R$, Wyler $S$, Forster $T$, et al. Safety and effectiveness of photoselective vaporization of the prostate (PVP) in patients on ongoing oral anticoagulation. Eur Urol 2007;51:1031-8. http://dx.doi. org/10.1016/i.eururo.2006.08.006

8. Heinrich E, Wendt-Nordahl $G$, Honeck $P$, et al. 120 W lithium triborate laser for photoselective vaporization of the prostate: Comparison with $80 \mathrm{~W}$ potassium-titanyl-phosphate laser in an ex-vivo model. J Endourol 2010;24:75-9. http://dx.doi.org/10.1089/end.2009.0051

9. Bachmann A, Muir GH, Collins EJ, et al. 180-W XPS Greenlight laser therapy for benign prostate hyperplasia: Early safety, efficacy, and perioperative outcome after 201 procedures. Eur Urol 2012;61:600-7. http://dx.doi.org/10.1016/i.eururo.2011.11.041

10. Ben-Zvi T, Hueber PA, Liberman D, et al. GreenLight XPS $180 \mathrm{~W}$ vs HPS $120 \mathrm{~W}$ laser therapy for benign prostate hyperplasia: A prospective comparative analysis after 200 cases in a single-center study. Urology 2013;81:853-8. http://dx.doi.org/10.1016/j.urology.2012.12.031

11. Hueber PAl, Liberman D, Ben-Zvi T, et al. 180W vs $120 \mathrm{~W}$ lithium triborate photoselective vaporization of the prostate for benign prostatic hyperplasia: A global, multicenter comparative analysis of perioperative treatment parameters. Urology 2013;82:1108-13. http://dx.doi.org/10.1016/i.urology.2013.03.059

12. Guidelines on the management of non-neurogenic male lower urinary tract symptoms (LUTS), incl. benign prostatic obstruction (BP0), European Association of Urology; 2014. http://bit.ly/lLEOMuv. Accessed February 2, 2015.

13. Muir G, Gomez-Sancha F, Bachmann A. Techniques and training with GreenLight HPS 120-W laser therapy of the prostate: Position paper. Eur Urol Suppl 2008;7:370-7. http://dx.doi.org/10.1016/i. eursup.2008.01.012

14. Woo H, Bachmann A, Gomez Sancha F, et al. An international multicenter experience with 180-W XPS photoselective vaporization of the prostate: First report on perioperative data, adverse outcomes and early functional results. J Urol 2011;185:e844. http://dx.doi.org/10.1016/i.juro.2011.02.2307

15. Ruszat $R$, Wyler $S$, Seifert $H-H$, et al. Photoselective vaporization of the prostate: Subgroup analysis of men with refractory urinary retention. Eur Urol 2006;50:1040-9. http://dx.doi.org/10.1016/i. eururo.2006.01.019

16. Ruszat R, Seitz M, Wyler SF, et al. Prospective single-centre comparison of 120-W diode-pumped solidstate high-intensity system laser vaporization of the prostate and 200-W high-intensive diodelaser ablation of the prostate for treating benign prostatic hyperplasia. BJU Int 2009; 104:820-5. http://dx.doi. org/10.1111/i.1464-410X.2009.08452.x
17. Woo HH, Hossack TA. Photoselective vaporization for prostatic obstruction with the 120-W lithium triborate laser: 1-year clinical outcomes. Int I Urol 2011;18:162-5. http://dx.doi.org/10.1111/i.14422042.2010.02686.x

18. Capitain C, Blazquez C, Martin MD, et al. Greenlight HPS 120-W laser vaporization versus transurethral resection of the prostate for the treatment of lower urinary tract symptoms due to benign prostatic hyperplasia: A randomized clinical trial with 2-year follow-up. Eur Urol 201 1;60:734-9. http://dx.doi. org/10.1016/i.eururo.2011.05.043

19. Tasci Al, Ilbey YO, Luleci H, et al. 120-W Greenlight laser photoselective vaporization of prostate for benign prostatic hyperplasia: Midterm outcomes. Urology 2011;78:134-40. http://dx.doi.org/10.1016/i. urology.2010.12.085

20. Al-Ansari A, Younes N, Sampige VP, et al. Greenlight HPS 120-W laser vaporization versus transurethral resection of the prostate for treatment of benign prostatic hyperplasia: A randomized clinical trial with midterm follow-up. Eur Urol 2010;58:349-55. http://dx.doi.org/10.1016/i.eururo.2010.05.026

21. Spaliviero M, Araki M, Culkin DJ, et al. Incidence, management, and prevention of perioperative complications of Greenlight HPS laser photoselective vaporization prostatectomy: Experience in the first 70 patients. J Endourol 2009;23:495-502. http://dx.doi.org/10.1089/end.2008.0299

22. Woo H, Reich O, Bachmann A, et al. Outcome of Greenlight HPS 120-W laser therapy in specific patient populations: those on retention, on anticoagulants, and with large prostates ( $\geq 80 \mathrm{ml}$ ). Eur Urol Suppl 2008;7:378-83. http://dx.doi.org/10.1016/i.eursup.2008.01.016

23. Malek RS, Kang HW, Peng YS, et al. Photoselective vaporization prostatectomy: Experience with a novel 180W $532 \mathrm{~nm}$ lithium triborate laser and fiber delivery system in living dogs. J Urol 2011;185:712-8. http://dx.doi.org/10.1016/i.juro.2010.09.076

24. Sohn JH, Choi YS, Kim SJ, et al. Effectiveness and safety of photoselective vaporization of the prostate with the 120 W HPS Greenlight laser in benign prostatic hyperplasia patients taking oral anticoagulants. Korean J Urol 2011;52:178-83. http://dx.doi.org/10.4111/kju.2011.52.3.178

Correspondence: Dr. Alper Eken, Acibadem Adana Hastanesi Urology Department, Cumhuriyet Cad № 66, Postal Code: 01130, Turkey; alpereken@yahoo.com 